\title{
Low Protein Solid Feed enhances Nitrogen Utilization by Urea Recycling in Veal Calves
}

\author{
H. Berends ${ }^{1}$, J.J.G.C. van den Borne ${ }^{1}$, B.A. Røjen ${ }^{2}$, J. van Baal ${ }^{1}$, and W.J.J. Gerrits ${ }^{1}$ \\ ${ }^{1}$ Animal Nutrition Group, Wageningen University, Wageningen, the Netherlands \\ ${ }^{2}$ Department of Animal Health and Bioscience, Aarhus University, Tjele, Denmark
}

This study was designed to quantify the effect of low-protein solid feed (SF) intake, provided in addition to milk replacer, on urea recycling in veal calves. We have shown previously thate the provision of low-protein SF increased the efficiency of $\mathrm{N}$ utilization for protein gain in veal calves, particularly towards the end of the fattening period. We hypothesized that recycling of urea originating from amino acids in milk replacer contributes substantially to the $\mathrm{N}$ retention of veal calves fed SF.

In order to quantify the contribution of urea recycling to $\mathrm{N}$ utilization, 48 Holstein Friesian male calves, $55 \pm 0.3 \mathrm{~kg}$ of bodyweight (BW), were fed $41 \mathrm{~g}$ of $\mathrm{MR} / \mathrm{kg}$ of $\mathrm{BW}^{0.75}$ per $\mathrm{d}$, and assigned to 1 of 4 levels of SF intake: $0,9,18$, or $27 \mathrm{~g}$ of DM of SF $/ \mathrm{kg}$ of $\mathrm{BW}^{0.75}$ per $\mathrm{d}$. The SF mixture consisted of $25 \%$ chopped straw, $25 \%$ chopped corn silage, and $50 \%$ concentrate, on a DM basis. Urea recycling was quantified at $164 \pm 1.6 \mathrm{~kg}$ of BW by intravenous administration of $\left[{ }^{15} \mathrm{~N}^{15} \mathrm{~N}\right]$ urea for $24 \mathrm{~h}$ after a priming dose to enrich the body urea- $\mathrm{N}$ pool to approximately 0.15 atom\% excess. Cumulative urine and feces over $68 \mathrm{~h}$ were analysed for urea isotopomers. In addition, a complete $\mathrm{N}$-balance was performed over a $4 \mathrm{~d}$ period. At slaughter rumen wall tissues were collected to measure mRNA expression of urea transporter-B (UT-B), aquaporins (AQP) 3 and 7. Urea recycling and mRNA data were analyzed by regression procedures using SF intake as regressor.

Urea entry rate, assumed equal to total urea synthesis, averaged $28.7 \mathrm{~g}$ urea- $\mathrm{N}$ per $\mathrm{d}$ and was not affected by SF intake $(P>0.05)$. Urea entry to the gut was $5.36 \mathrm{~g}$ urea-N per $\mathrm{d}$ for calves without $\mathrm{SF}$, and increased with SF intake $\left(0.38 \pm 0.09 \mathrm{~g}\right.$ urea- $\mathrm{N}$ per $\mathrm{g} \mathrm{DM}$ from $\mathrm{SF} / \mathrm{kg}^{0.75}$ per $\left.\mathrm{d} ; P<0.05\right)$. Subsequently, the return of urea to the ornithine cycle was $1.23 \mathrm{~g}$ urea-N per $\mathrm{d}$ for calves without SF and increased with increasing SF intake $\left(0.11 \pm 0.03\right.$ g urea-N per g DM from SF $/ \mathrm{kg}^{0.75}$ per $\left.\mathrm{d} ; P<0.05\right)$. Excretion with feces averaged $0.19 \mathrm{~g}$ urea- $\mathrm{N}$ per $\mathrm{d}$ for calves without $\mathrm{SF}$ and increased with increasing SF intake $\left(0.08 \pm 0.01 \mathrm{~g}\right.$ urea-N per g DM from SF $/ \mathrm{kg}^{0.75}$ per $\left.\mathrm{d} ; P<0.05\right)$, probably undigested microbial $\mathrm{N}$. As a net result, urea used for anabolic purposes averaged $3.94 \mathrm{~g}$ urea-N per $\mathrm{d}$ and increased with SF intake $\left(0.20 \pm 0.01 \mathrm{~g}\right.$ urea-N per g DM from SF $/ \mathrm{kg}^{0.75}$ per $\left.\mathrm{d} ; P<0.05\right)$. The increase in urea used for anabolic purposes explained $41 \%$ of the increase observed in $\mathrm{N}$ retention. The mRNA expression of UT-B was increased more than five-fold when SF was provided, irrespective of level. The mRNA expression of AQP3 increased linearly $(P<0.05)$ with SF intake, whereas mRNA expression of AQP7 did not. In conclusion, an increase in low-protein SF intake was accompanied by an increased gut entry rate of urea- $\mathrm{N}$, explaining a substantial portion of the observed increase in $\mathrm{N}$ retention. Furthermore, the provision of SF rather than its level stimulates expression of mRNA of urea transporter $B$ in the rumen wall.

Keywords: urea recycling, nitrogen utilization, urea transporter B, aquaporin 